\section{The Problem with Pin Site Infection}

\section{Jennie Walker*}

Department of Nursing, University of Nottingham, UK

External fixation allows fixation and manipulation of multiple bone segments and can be used both in limb lengthening as well as the management and reconstruction of complex injuries. One of its key advantages is that it offers an appropriate method of stabilization in patients who have poor soft tissue integrity, chronic infection or are not systemically optimized for surgery [1].

Pin Site Infection (PSI) has been described as so common that "it seems reasonable to consider it unavoidable". Infection can range from local soft tissue infection and cellulitis to osteomyelitis, bacterial endocarditis and septic arthritis, in severe cases this may progress to septicaemia [2-4]. In many cases minor infection can be remedied with increased pin site care and antibiotic therapy, whereas major infection requires prolonged treatment with systemic antibiotics and often the removal of pins.

Recognising infection of the pin site or surrounding tissues is essential to enable effective early management of infection. Classification of PSI varies within the literature, with some studies using clinical judgement of infection [5] and others preferring to use microbiological diagnosis of infection [6]. Many pin site grading tools are complex and time consuming for clinicians to use with varying inter-rater reliability when classifying or grading the extent of erythema, tenderness and swelling of an infected pin site. Clint et al. [7] system offers a simplistic approach, which classifies pin sites as 'Good', 'Bad' or 'Ugly', based on factors such as erythema and pain. Similarly, Santy J [8] criteria describes pin sites as 'calm', 'irritated' or 'infected' and takes into account patient and clinician observations. Biofilms on the pin surface result in persistent, chronic and recurring infection of the pin site. Even with careful monitoring of the trends of PSI in each fixator it is difficult to distinguish between ongoing infection associated with biofilm formation, and new infection resulting from different organisms.

Reported rates of pin complications range from $7.9 \%$ [9] to $100 \%$ $[10,11]$, partly due to the lack of a uniform definition and classification system to determine and quantify PSI [12]. Different research methodologies and classification criteria make accurate comparisons of interventions difficult to interpret and relate to clinical practice. Erratic documentation of pin site infection and pin site care within the literature, along with consideration of too many variables, or failure to include control groups within studies makes further identification of successful actions difficult. This not only restricts translation of research findings in to practice, but hinders progression of evidenced based care within this area

A lack of clear evidence and consensus within the literature has resulted in inconsistent pin site management and the subsequent failure to prevent or reduce the risk of PSI on a regular basis. A key step to preventing PSI is to prevent the colonisation of the pins and wires in a manner which is effective and acceptable to both clinicians and patients. Further research needs to be based on good methodology using standardised tools and variables which can be easily translated in to clinical practice.

\section{Acknowledgement}

Jennie Walker has been awarded a Fellowship from Arthritis Research UK to research pin site infection.

\section{References}

1. Thiryayi WA, Naqui Z, Khan SA (2010) Use of Taylor Spatial frame in compression arthrodesis of the Ankle: A Study of 10 cases. J Foot Ankle Surg 49: 182-187.

2. Gibbons CT, Montgomery RJ (2003) Management of foot and ankle conditions using Ilizarov technique. Curr Orthop 17: 436-446.

3. Fragomen AT, Rozbruch SR (2007) The mechanics of external fixation. HSS 3: $13-29$.

4. Antoci V, Ono CM, Antoci V Jr, Raney EM (2008) Pin-tract infection during limb lengthening using external fixation. Am J Orthop (Belle Mead $\mathrm{NJ}$ ) 37 E150-E154.

5. Katsenis D, Bhave A, Paley D, Herzenberg JE (2005) Treatment of malunion and nonunion at the site of an ankle fusion with the llizarov apparatus. J Bone Joint Surg Am 87: 302-309.

6. Pommer A, Muhr G, Dávid A (2002) Hydroxyapatite-coated Schanz pins in external fixators used for distraction osteogenesis : a randomized, controlled trial. J Bone Joint Surg Am 84: 1162-1166.

7. Clint SA, Eastwood DM, Chasseaud M, Calder PR, Marsh DR (2010) The "Good, Bad and Ugly" pin site grading system: A reliable and memorable method for documenting and monitoring ring fixator pin sites. Injury 41: 147 150

8. Santy J (2011) A review of pin site wound infection assessment criteria International Journal of Orthopaedic and Trauma Nursing 14: 125-131.

9. Battle J, Carmichael KD (2007) Incidence of pin track infection in children's fractures treated with Kirschner wire fixation. J Pediatr Orthop 27: 154-157.

10. Hosny GA (2005) Unilateral humeral lengthening in children and adolescents. J Pediatr Orthop B 14: 439-443.

11. Blum AL, BongioVanni JC, Morgan SJ, Flierl MA, dos Reis FB (2010) Complications associated with distraction osteogenesis for infected non-union of the femoral shaft in the presence of a bone defect: a retrospective series $J$ Bone Joint Surg Br 92: 565-570.

12. Sato W, Ohnishi I, Nishimura N, Nakase T, Tsuchiya H, et al. (2003) Correction of tibial deformity in adults. J Orthop Sci 8: 306-312.

*Corresponding author: Jennie Walker, Department of Nursing, University of Nottingham, UK, E-mail: Jennie.walker@nottingham.ac.uk

Received May 24, 2012; Accepted May 26, 2012; Published May 28, 2012

Citation: Walker J (2012) The Problem with Pin Site Infection. J Nurs Care 1:e111. doi:10.4172/2167-1168.1000e111

Copyright: @ 2012 Walker J. This is an open-access article distributed under the terms of the Creative Commons Attribution License, which permits unrestricted use, distribution, and reproduction in any medium, provided the original author and source are credited. 